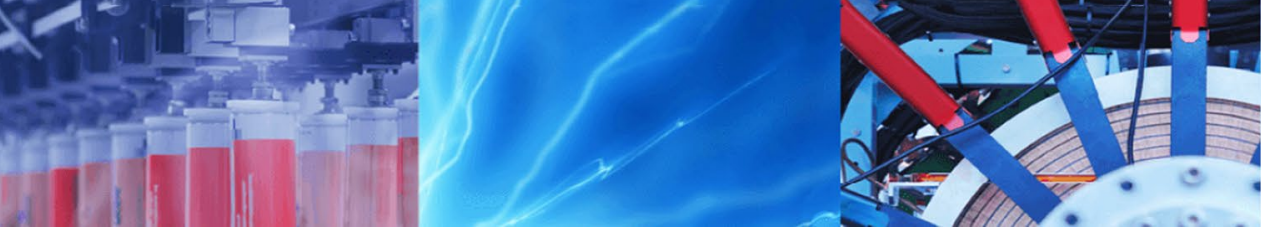

Research Article

\title{
Mineralogy, geochemistry and genesis of bentonite deposits in Lam Narai volcanic belts, Lop Buri province, central Thailand
}

\author{
Nuchit Siritongkham ${ }^{1} \cdot$ Weerapan Srichan ${ }^{2}$ (]) Somboon Khositanont ${ }^{1} \cdot$ Phisit Limtrakun $^{2}$
}

Received: 8 February 2020 / Accepted: 15 April 2020 / Published online: 23 April 2020

(c) Springer Nature Switzerland AG 2020

\begin{abstract}
Alteration in the subaqueous basaltic rock of the Lam Narai volcanic belts, Lop Buri province, central Thailand has resulted in the formation of bentonite deposits. The bentonite deposits have been geological, mineralogical and geochemical studied to determine their genesis. The characteristics of the bentonites were examined by using X-ray Diffractometer and Scanning Electron Microscope with Energy Dispersive Spectroscopy. The mineralization zone of bentonite shown $\mathrm{X}$-ray diffraction patterns of montmorillonite as the major constituent with minor hematite and calcite. Morphology of the minerals and groundmass in the bentonite deposits display the "cornflake," "oak leaf," or "cellular" textures that are typical and representative of montmorillonite in smectite group and composed of $\mathrm{Si}, \mathrm{Al}, \mathrm{O}, \mathrm{Ca}, \mathrm{Mg}$ and Fe in their chemical compositions. Geochemistry of the bentonite and their parental volcanic associations were analyses by using X-ray Fluorescence Spectrometry for major and trace elements. The representative samples were selected for the analysis of the rare-earth elements by using Inductively Coupled Plasma-Mass Spectrometry. The AI-CCPI alteration box plot revealed that the bentonite is mainly altered by hydrothermal alteration associated with basaltic layer in the Lam Narai volcanic belt. The basaltic layers in this area are composed of pillow lavas, inter-pillow and basic glassy inter-pillow (hyaloclastite) that indicated the subaqueous environment. The smectite formed by hydrothermal alteration from altered basic glassy inter-pillow (hyaloclastite) in the basaltic layers. Hydrothermal fluids in this area are possibly derived from the major fault along Pa Sak River or the youngest intrusive rocks in the Lam Narai volcanic terrain.
\end{abstract}

Keywords Bentonite $\cdot$ Basaltic layer $\cdot$ Lam Narai volcanic belt $\cdot$ Hydrothermal alteration

\section{Introduction}

Bentonites are clay rocks made principally of smectite of the montmorillonite-beidellite series. They form mainly from the alteration of pyroclastic and/or volcaniclastic rocks. Bentonites generally form by diagenetic or hydrothermal alteration, favoured by fluids that leach alkali elements and by high Mg content. Smectite composition is partly controlled by parent rock chemistry.

Bentonite is composed of smectite clay minerals, and their properties have a unique crystal structure and habit.
The mineral consists of silica and alumina was arranged in sheet-like units, the individual sheets are loosely tied together that can lead to water enter between the sheets, which made its separating. The water molecules change the composition and structure of smectite to unbalanced with negative charge, which is balanced by an absorbed cation such as sodium, calcium, etc. Consequently, the use of bentonite is depended on their properties in water systems, for example, viscosity, thixotropy, plasticity, bonding, strength, shear strength, water impedance, etc. Because of foregoing characteristics, the bentonite was the essential

\footnotetext{
$\triangle$ Weerapan Srichan, weerapan.s@cmu.ac.th; Nuchit Siritongkham, nuchit_sk@hotmail.com; Somboon Khositanont, khositanont.s@gmail.com; Phisit Limtrakun, phisit.l@cmu.ac.th|'ineral Resources Division, Department of Mineral Resources, Bangkok, Thailand. ${ }^{2}$ Department of Geological Sciences, Faculty of Science, Chiang Mai University, Chiang Mai, Thailand.
} 
constituents in drilling mud, foundry-sand bond, binder for pelletizing iron ore, and for bleaching liquids (filtering, clarifying, and decolorizing). The minor uses include a carrier for pesticides and fertilizers, filler in paint, adhesive, and pharmaceutical products, binder for animal feed, sealant for waterproofing reservoirs and canals, and as a catalyst for oil refining [1].

The Cenozoic volcanic in Lam Narai area (Fig. 1), Lop Buri province consists of massive rhyolite, glassy breccia, pitchstone perlite and pyroclastic deposits which are covered by basaltic flow. The pyroclastic rocks associated with bentonite deposit which derived from hydrothermal alteration of rhyodacite and vitric tuff into montmorillonite [2].

Mineralogy and genesis of bentonite deposit related Cenozoic volcanic terranes in Lam Narai area have not been studied in detail. Petrography, ore microscopy and geochemistry of pyroclastic rocks, volcanic rocks, and bentonite are determining the alteration processes of the pyroclastic rocks and volcanic rocks in association to bentonization of this study.
Fig. 1 Distribution of Cenozoic volcanic rocks in Thailand and the study area [3]

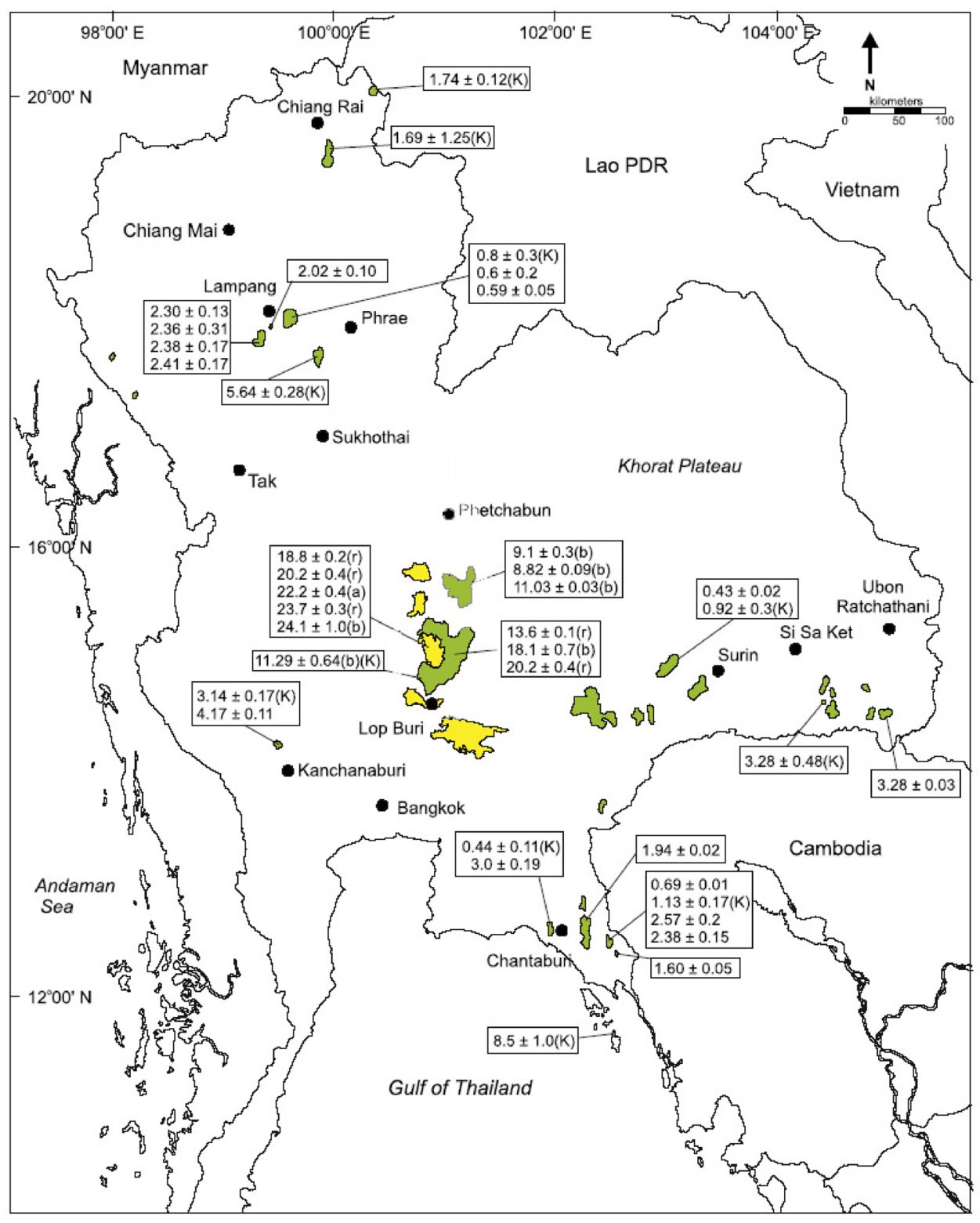

Explanation

Cenozoic basalt
Tertiary volcanic
Study area 


\section{Materials and methods}

\subsection{Geologic setting}

The bentonite deposit in the Lam Narai Volcanic Belt is located at the Khao Pa Khon area, about $6 \mathrm{~km}$ south of Chai Badan district, Lop Buri province. The geology of the study area composed of mafic-intermediate composition lava overlain by a silicic lava flow in Tertiary and ending with late basaltic lava in a flat area (Fig. 2).
The south-eastern part of the Khao Pa Khon covered by Quaternary alluvial deposit which is underlain by Permian limestone in the subsurface. Structural geology in the area is the fault, align in the north-south direction, which Pa Sak River is the fault-controlling stream in Lam Narai volcanic field [4]. The cross-cut in open pit mining show the relationship of volcanic rocks in the field and schematic diagram of the Khao Pa Khon volcanic sequence, as shown in Fig. 3.
Fig. 2 Geologic map of the bentonite deposit at Khao Pa Khon area, Chai Badan district, Lop Buri province [5]

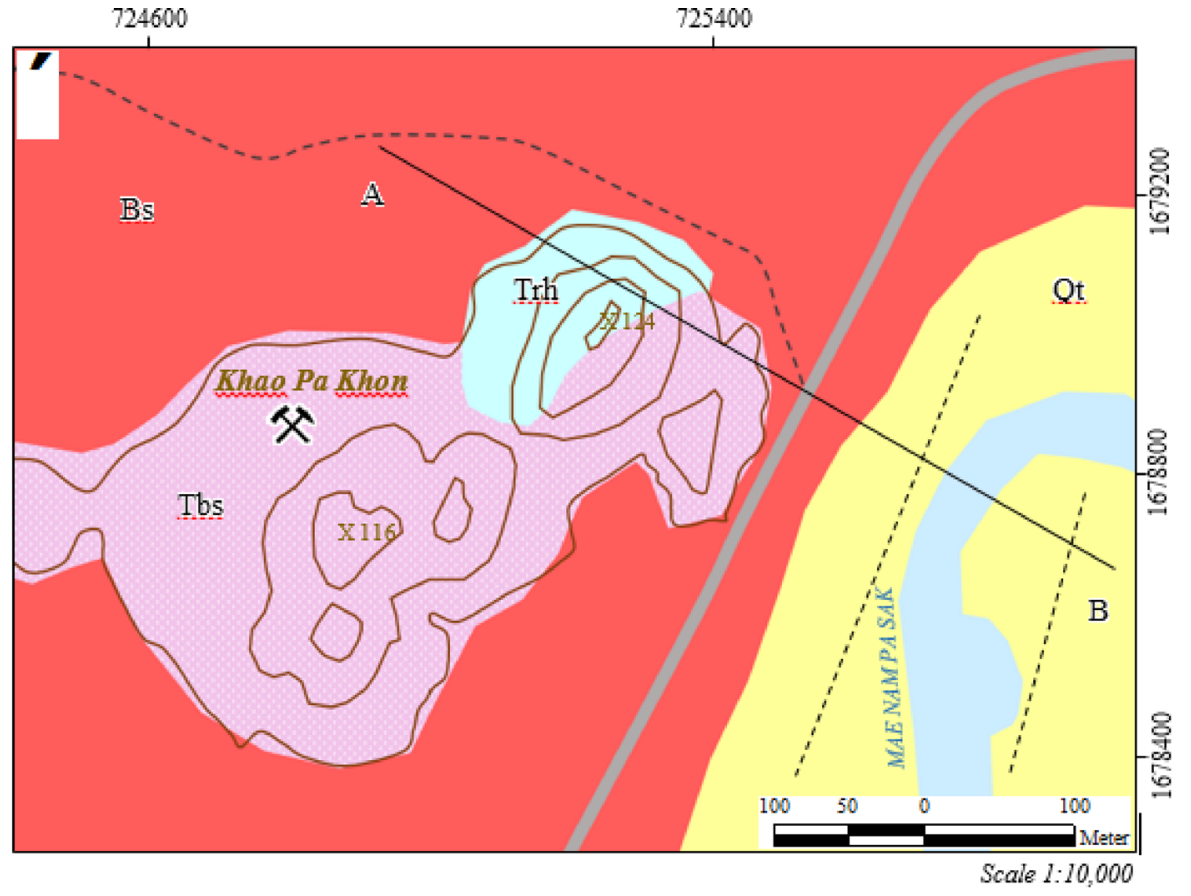

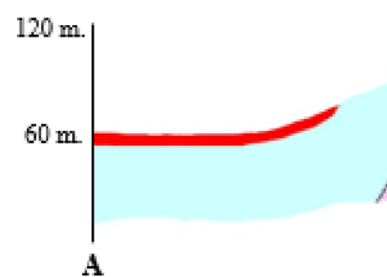

\section{Legend}

Bs Quaternary basalt

Qt Quaternary sediment

Trh Tertiary rhyolite

Tbs Tertiary basaltic andesite

Permian limestone 


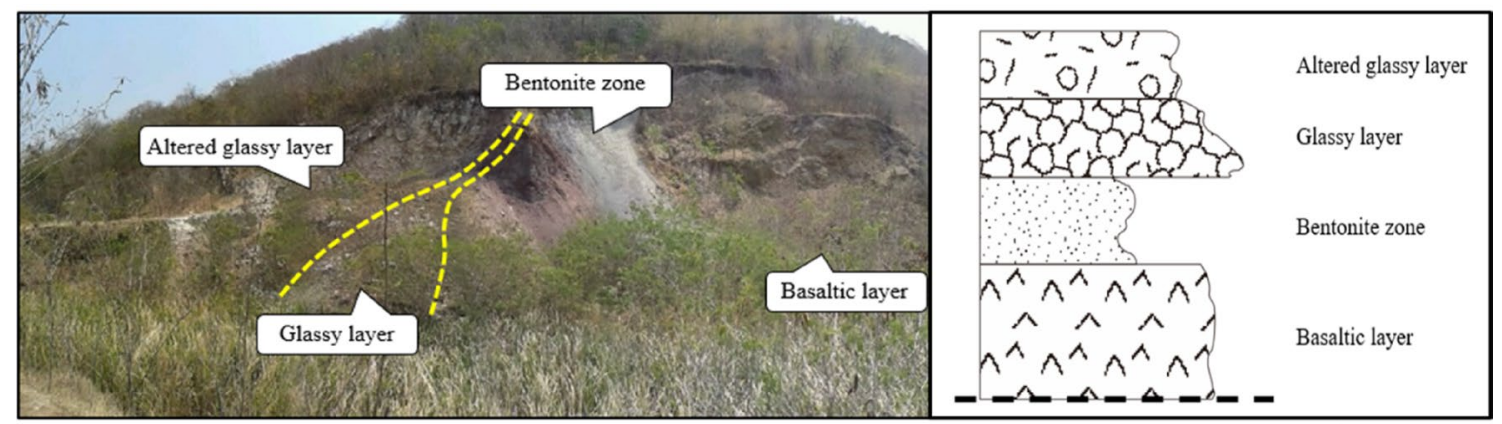

Fig. 3 Photograph shows the field relationship of rock units and lithostratigraphic column of the Khao Pa Khon bentonite deposit in Lam Narai volcanic belt

\subsection{Methodology}

Field observation, rock sampling, lithology and petrography of the bentonite deposit in Cenozoic Volcanic Belts in Lam Narai area, Lop Buri province were determined in this study. The field works were allocated to determine the various lithological units and their relationship, including characteristics of bentonitzation across the profiles.

Rock samples of parent rock, alteration zone and enclosing rocks were collected and prepared as standard thin section ( $0.03 \mathrm{~mm}$ thick) for petrographic study to determine their characterize mineral compositions, texture and their alteration. Representative bulk samples of clay fraction which prepared from volcanic rocks and alteration zone were analyzed by X-ray diffraction (XRD). Powdered rock samples were chemically analyzed in major oxides, trace elements, rare-earth elements (REE) and loss on ignition (LOI). The major oxides and trace elements were done by a Phillips-MagixPRO wavelength dispersive X-ray Fluorescence Spectrometer. Loss on ignition (LOI) was determined by heating $1 \mathrm{~g}$ of powder sample at $1000^{\circ} \mathrm{C}$ for $12 \mathrm{~h}$ and reweighting. For X-ray diffraction experiments and LOI procedures were carried out at the Department of Geological Sciences, Faculty of Science, Chiang Mai University. The representatives of samples were selected for analyzed the rare-earth elements (herein REE) ( $\mathrm{La}, \mathrm{Ce}, \mathrm{Pr}, \mathrm{Nd}, \mathrm{Sm}, \mathrm{Eu}, \mathrm{Gd}, \mathrm{Tb}, \mathrm{Dy}$, $\mathrm{Ho}, \mathrm{Er}, \mathrm{Tm}, \mathrm{Yb}$, and Lu). Analyses were done using ICP-MS (Inductively Coupled Plasma-Mass Spectrometry), carried out at SGS Minerals Services Geochemical Laboratory in Canada.

The SEM studies were performed using a Quanta 200 3D, FEl field emission instrument in order to determine the particle morphologies and textural relationships. The samples were studied at Electron microscope research and service center, Faculty of Science, Chiang Mai University.

\section{Result and discussion}

The Lam Narai volcanic field are parts of Cenozoic volcanic rocks in central plain, Thailand. The Lam Narai volcanic rocks are associated to bentonite deposit at Khao Pa Khon area which located in Chai Badan district, Lop Buri province. The volcanic rocks can be classified into four layers as followed by basaltic layer, bentonite zone, glassy layer, and altered glassy layer, relatively.

From their petrography, geochemistry, tectonic setting, and field relationship have demonstrated the volcanic rocks can be separated into mafic group with bentonite zone and felsic group (Fig. 4).

\subsection{Mafic group}

Mafic group includes basaltic layer (Fig. 4a) and bentonite zone. The basaltic layer is composed of basaltic rock in mafic to intermediate-composition. The rock is porphyritic texture and basic glassy texture. The basaltic layer is hypocrystalline, fine-grained and porphyritic texture. Groundmass consists of glass and plagioclase microlites. Fracture and cavities have been found and normally infilling by carbonate, quartz, chlorite, and sericite. In addition, the mineral phenocrysts and groundmass are intensively altered. The bentonite zone is composed of the smectite clay mineral.

Geochemically, the relationship between $\mathrm{Zr} / \mathrm{Ti}$ against $\mathrm{Nb} / \mathrm{Y}$ ratio is in range of $0.0139-0.0155$ and $0.4631-0.6389$, respectively. These compositional ranges correspond to alkaline to sub-alkaline basalt affinity (Fig. 5). The chondrite normalized REE patterns of basaltic layer and bentonite zone show slightly LREE enrichment and relatively HREE depletion (Fig. 6), with chondrite-normalized La/Sm, $\mathrm{Sm} / \mathrm{Yb}$ and $\mathrm{La} / \mathrm{Yb}$ in ranges of 2.58-2.79, 1.74-2.36 and 4.50-6.48, typical of within-plate tholeiites and transitional tholeiites. The $\mathrm{Zr}-\mathrm{Y}$ versus $\mathrm{Zr}$ and the $\mathrm{Zr}-\mathrm{Nb}-\mathrm{Y}$ discrimination diagram are supporting within-plate basalts. The REE 

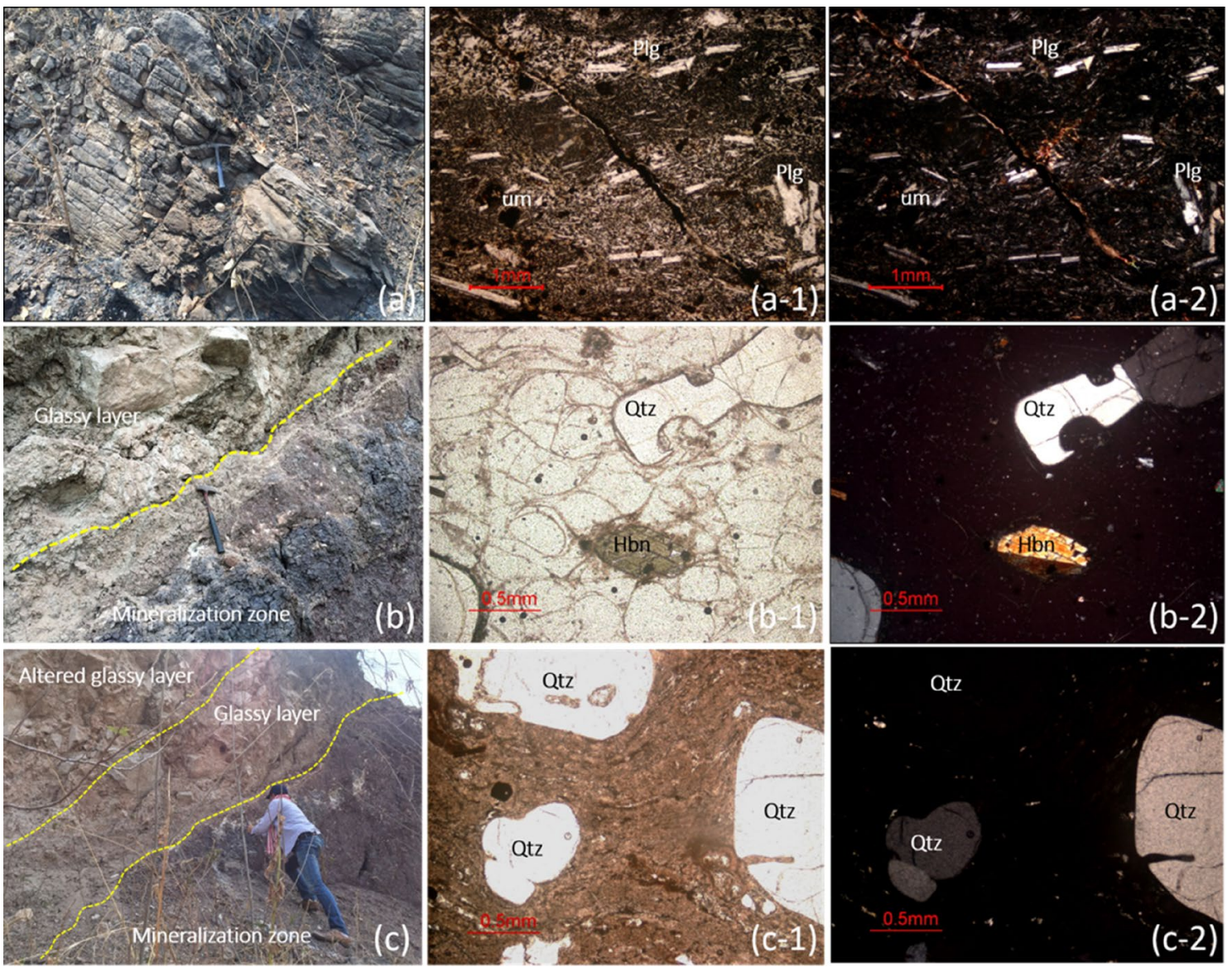

Fig. 4 Outcrop of basaltic layer (a), bentonite zone, glassy layer (b) and altered glassy layer (b, c) of the Khao Pa Khon bentonite deposit in Lam Narai Volcanic Belt (in Fig. 3). Photomicrographs of a representative basaltic lava showing plagioclase phenocrysta (Plg), plagioclase glomerocryst, dark glass, and unidentified mafic mineral (um). (a-1. Ordinary light and a-2. Crossed polars). Photomicrographs of a representative glassy bed showing vitrophyric

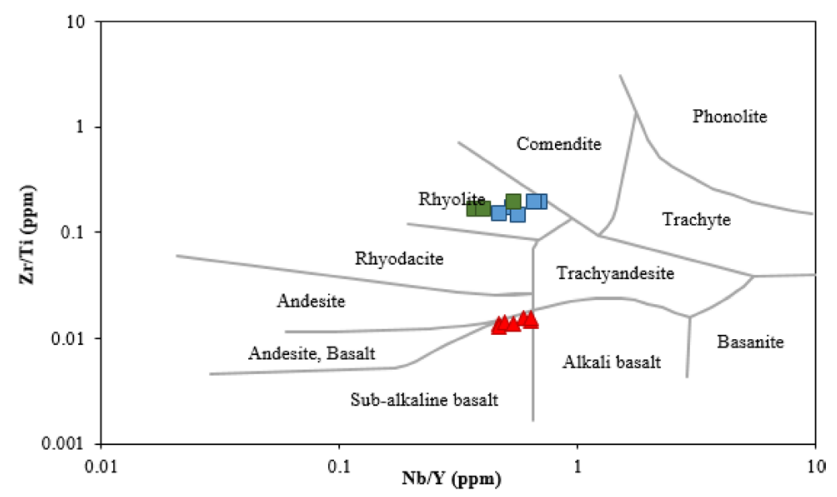

A Basaltic layer $\square$ Glassy Layer $\square$ Altered glassy layer

Fig. 5 Plot of $\mathrm{Zr} / \mathrm{TiO} 2$ versus $\mathrm{Nb} / \mathrm{Y}$ for the volcanic rocks samples from Lam Narai area, field boundaries for different magma types is taken from [6] texture with perlitic cracks containing hornblende $(\mathrm{Hbn})$ in perfect cleavage and quartz (Qtz) embayment phenocrysts (b-1. Ordinary light and b-2. Crossed polars). photomicrographs of a representative altered glassy layer displaying vitrophyric texture. Quartz (Qtz) megacrysts in glassy groundmass with flow band (c-1. Ordinary light and c-2. Crossed polars)

pattern of the basaltic layer and bentonite zone have a similar pattern and suggested that the basaltic layer and bentonite zone were generated from the same magma (Fig. 6).

\subsection{Felsic group}

Felsic group includes the glassy layer (Fig. 4b) and altered glassy layer (Fig. 4c). The glassy layer is pale-dark green to grey color, and the altered glassy bed are pale yellow or reddish-purple. They are commonly shown irregular hackly fracture with porphyritic texture in the glassy groundmass and usually show perlitic crack. The phenocrysts are plagioclase and hornblende/biotite. The glassy bed and altered glassy bed are included vitrophyric texture. The groundmass consists average in $85 \%$ of glass and $15 \%$ of phenocryst. The phenocrysts are composed of quartz, 
Fig. 6 Chondrite-normalized REE patterns for the representative samples from Lam Narai volcanic belt. Normalizing values used are those of [7]

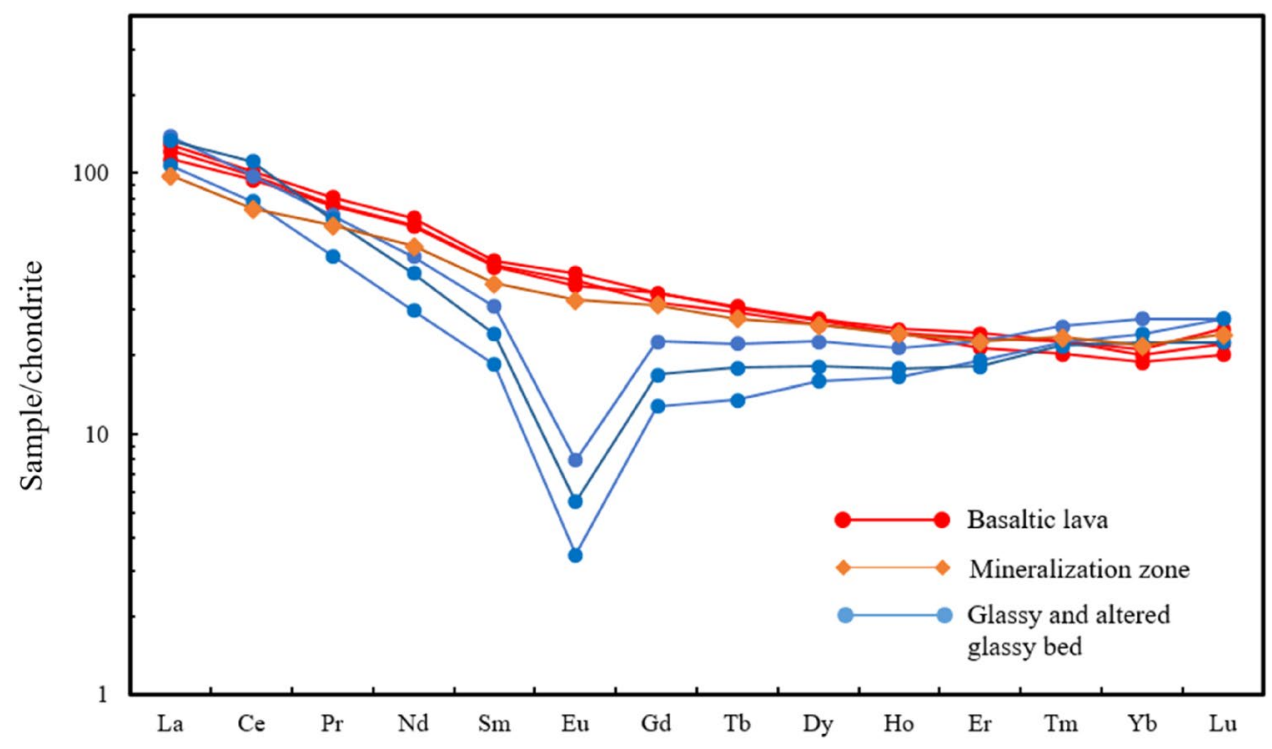

plagioclase, sanidine, and hornblende/biotite. The glassy layer and altered glassy layer generally contain a small vein or cavities, mostly filled with microcrystalline quartz and zeolite. The glassy layer often displays perlitic cracks, whereas altered glassy layer often observed spherulite that indicated high-temperature devitrification from glassy layer.

Geochemically, the relationship between alkali and silica on TAS diagram shows both layers are fall in rhyolite field. Relationship between $\mathrm{Zr} / \mathrm{Ti}$ against $\mathrm{Nb} / \mathrm{Y}$ ratios is in range of $0.1483-0.1943$ and $0.3682-0.6901$, respectively. These compositional ranges correspond to calc-alkaline rhyolite affinity (Fig. 6). The glassy and altered glassy layer shows relatively slightly LREE enrichment and flat HREE, with chondrite-normalized $\mathrm{La} / \mathrm{Sm}, \mathrm{Sm} / \mathrm{Yb}$ and $\mathrm{La} / \mathrm{Yb}$ in ranges of $4.48-5.86,1.11-0.76$ and $4.44-5.93$, respectively. These groups have negative europium anomalies and indicate plagioclase fractionation. The REE pattern of the glassy layer and altered glassy layer have a similar pattern and suggested that the two layers were formed the same magma.

However, the silica gap from major element fractionation diagram and non-parallel of REE-patterns of these volcanic layers at the Lam Narai area assumed that the magma from mafic group and felsic group derived from different magmatic source or non co-magmatic source.

\subsection{Bentonite deposits}

The bentonite deposit in the Lam Narai area contains smectite of the montmorillonite series (Fig. 7) which present as a major mineral in bentonite zone, and contain minor mineral in basaltic layer. Photomicrographs scanning electron microscope of the clay fraction in alteration
Fig. 7 Representative X-ray diffraction traces of bentonite zone (smectite in bentonite) in the Lam Narai volcanic belt

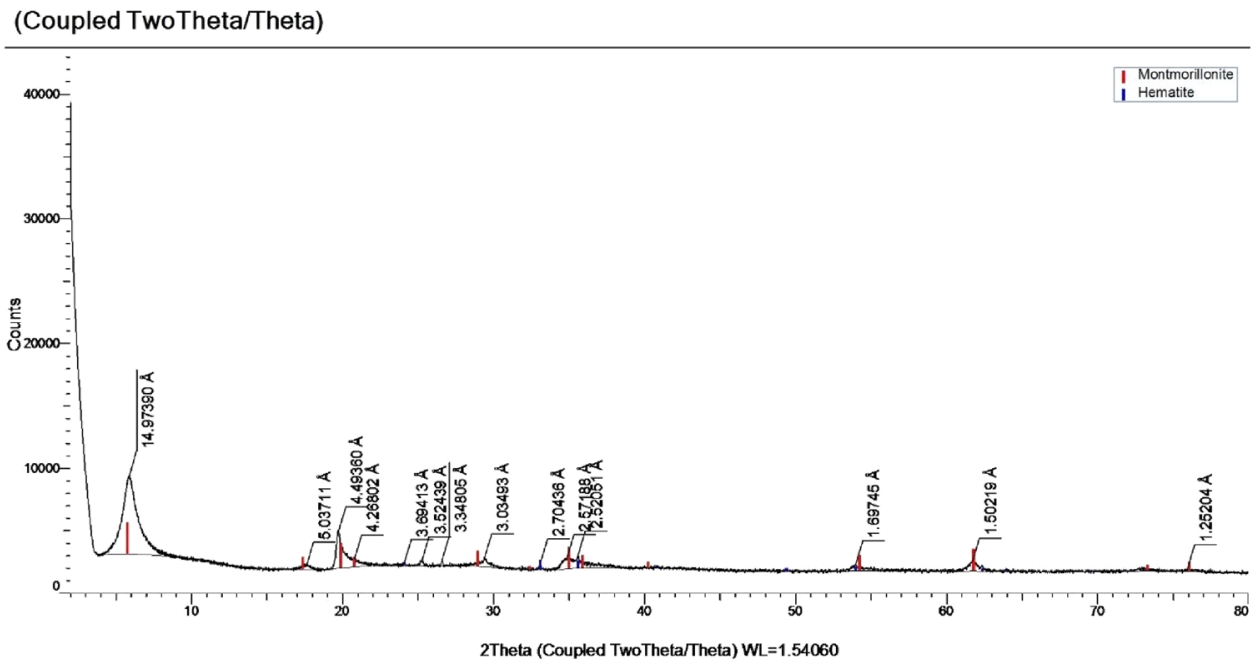


zone display the "cornflake," "oak leaf," or "cellular" textures that are typical and representative of montmorillonite in smectite group (Fig. 8). The montmorillonite is composed of $\mathrm{Si}, \mathrm{Al}, \mathrm{O}, \mathrm{Ca}, \mathrm{Mg}$ and $\mathrm{Fe}$, in the EDX analysis.

\subsection{Geochemistry of bentonite}

The smectite in bentonite zone display similar bulk-basaltic rock chemical characteristic and determine that the basaltic rock is the parent rock of smectite in the study area. According to Christidis [8], the alkalis and Si are usually migration and $\mathrm{Mg}$ is required during the alteration of the parent rock to form smectites in the bentonite formation process.

The chemical distribution of major oxides elements between smectite (bentonite zone) and bulk composition of parent rocks (basaltic lava) is depicted in elemental concentration diagrams. The diagrams show that the plotted of $\mathrm{Al}$ and Fe seem to be enriched and $\mathrm{Mg}$ are highly enriched in the concentration of smectite, relative to the parent rock because they are present mainly in octahedral sheet of smectite. $\mathrm{Si}, \mathrm{Ca}$, and $\mathrm{Na}$ are enriched in parent rocks relative to the smectite because they occur in minerals other than smectite that are mainly in the bentonite. $\mathrm{K}$ is depleted in smectite relative to parent rock because alkali is mobile and migration to the environment.

In additional, weathering trends can be displayed on an $\mathrm{Al}_{2} \mathrm{O}_{3}-\left(\mathrm{CaO}+\mathrm{Na}_{2} \mathrm{O}\right)-\mathrm{K}_{2} \mathrm{O}$ diagrams [9]. The ternary plot (Fig. 9) is showing the major element composition and weathering trends variation accompanying the alteration of basalt to bentonites. The trends illustrated initial stage of chemical weathering from plagioclase to smectite.

Considering the chondrite-normalized patterns of the REE redistribution in representative samples of bentonites (alteration zone) and comparing them with the REE abundances in representative samples of unaltered volcanic (basaltic lava), a relatively small shift or flat pattern is indicated by the total amount of these elements in both kinds

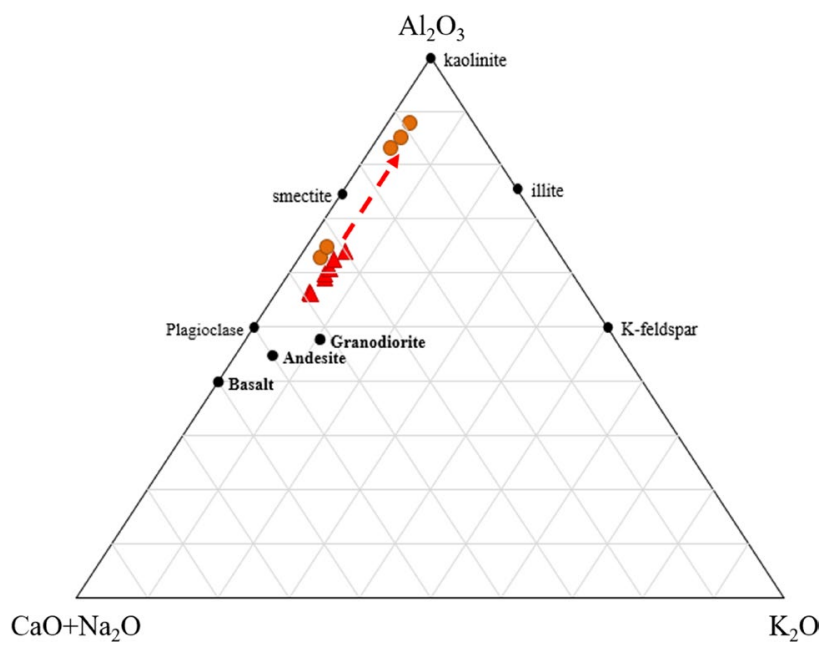

Fig. 9 Plots of the basalt parent rocks and their altered products on the $\mathrm{Al}_{2} \mathrm{O}_{3}-\left(\mathrm{CaO}+\mathrm{Na}_{2} \mathrm{O}\right)-\mathrm{K}_{2} \mathrm{O}$ diagrams. Basaltic lava (parent rocks) are red triangle, bentonite zone (bentonite) are brown circle

of samples. This suggested that REE element ratio in the parent rock was similar to the bentonite sample (Fig. 10).

The alteration box plot by [10] is $x-y$ bivariate plot with Ishikawa alteration index (AI) plot in X-axis and chloritecarbonate-pyrite index (CCPI) plot in Y-axis. The diagram exhibits hydrothermal alteration assemblages from diagenetic albite- or albite + K-feldspar-bearing assemblages. The position of least-altered volcanic rocks plot within a rectangle near the middle. Feldspar, phyllosilicate, carbonate and several other alteration mineral compositions plot around the margins of the Alteration box plot (Fig. 11).

The AI-CCPI alteration box plot revealed that the basaltic layer and bentonite zone are high values of CCPI reflect their mafic composition, but Al value of bentonite zone are higher than those of basaltic layer according to their intensely altered (Fig. 11). Basaltic layers are plotted close to- and within "least altered box" (rectangle near the middle) and bentonite zone are plotted in altered
Fig. 8 Electron micrographs of montmorillonite textures observed in the bentonite zone. a SEM indicating wellcrystallised montmorillonite with cornflake texture, $\mathbf{b}$ the basaltic unit altered to montmorillonite
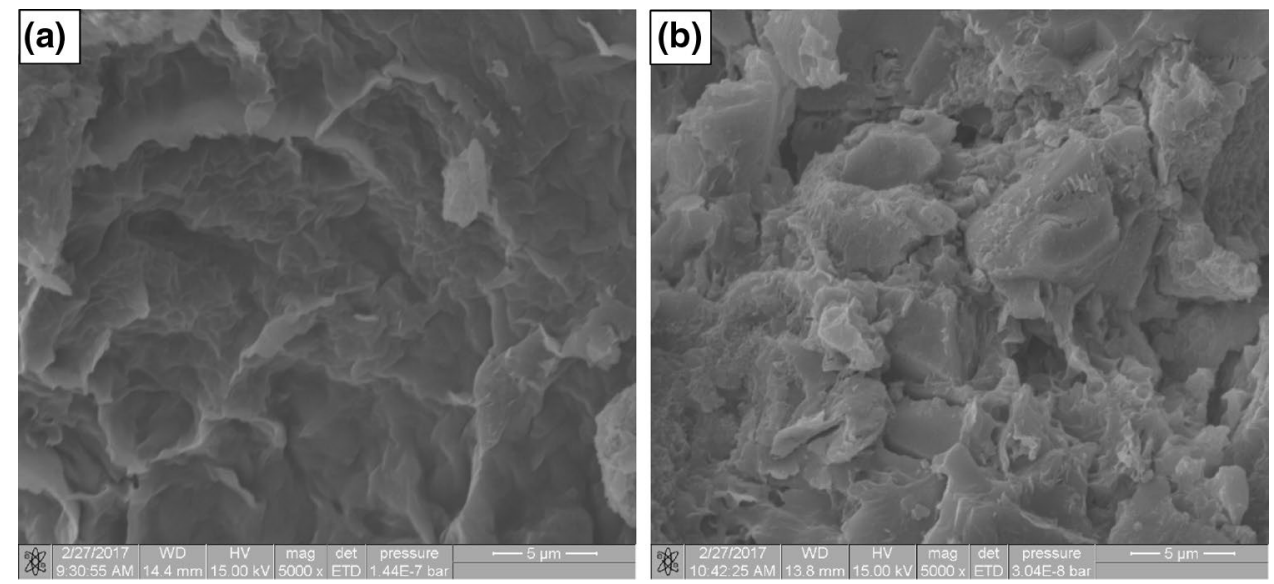
Fig. 10 Relative of REE elements of bentonites in relation to the parent basaltic rock of the Lam Narai volcanoic belt

Fig. 11 Al-CCPI Alteration box plot for Lam Narai volcanic rocks. Basaltic lava are red triangle, bentonite zone are brown circle, glassy layer are green square, and altered glassy layer are blue square
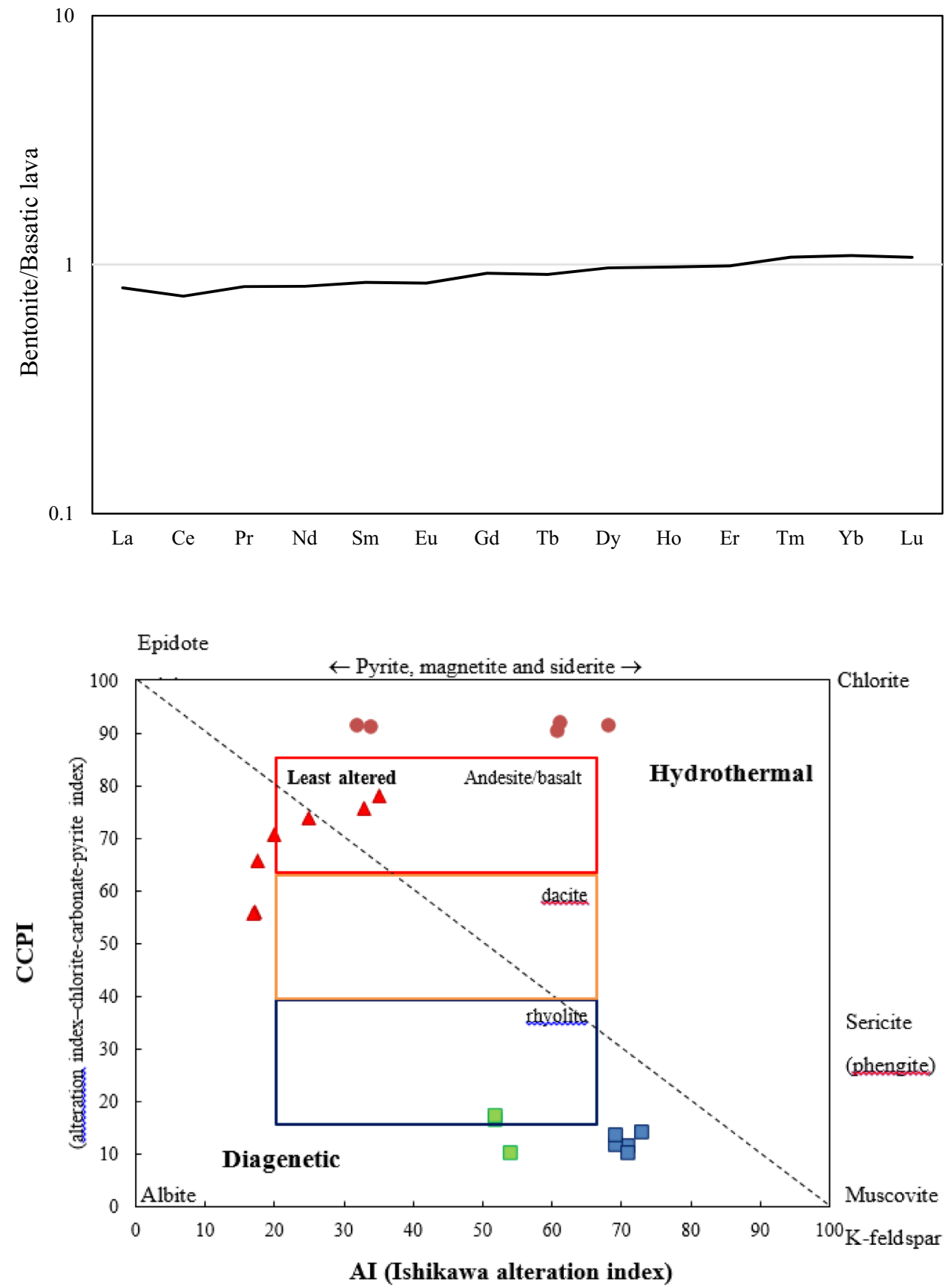

rocks zone. The glassy layer and altered glassy layer are low values of CCPI reflect the felsic components. Glassy layer is plotted close to- and within "least altered box" and altered glassy layer are confined to altered igneous rock, due to Al ranging from 69.13 to 73.12 and CCPI ranging from 9.84 to 14.10 . The calculated data of all units trends mainly toward hydrothermal alteration phase rather than the diagenetic phase. The bentonite zone is plotted in the altered rocks zone. The calculated data of all units trends mainly toward hydrothermal alteration phase.

\subsection{Discussion}

The bentonite zone in the study area was positive relatively with alteration of the basaltic layer. The basaltic layer area presented holocrystalline to hypocrystalline groundmass signify that the interaction between hot magma and cold water (quenching). The spheroidal weathering of the layer cause effected from quenching in rim and are commonly glassy and intricately fractured that are typical of pillow lava. Pillows are diagnostic of the subaqueous emplacement of lavas surrounded

\section{SN Applied Sciences}




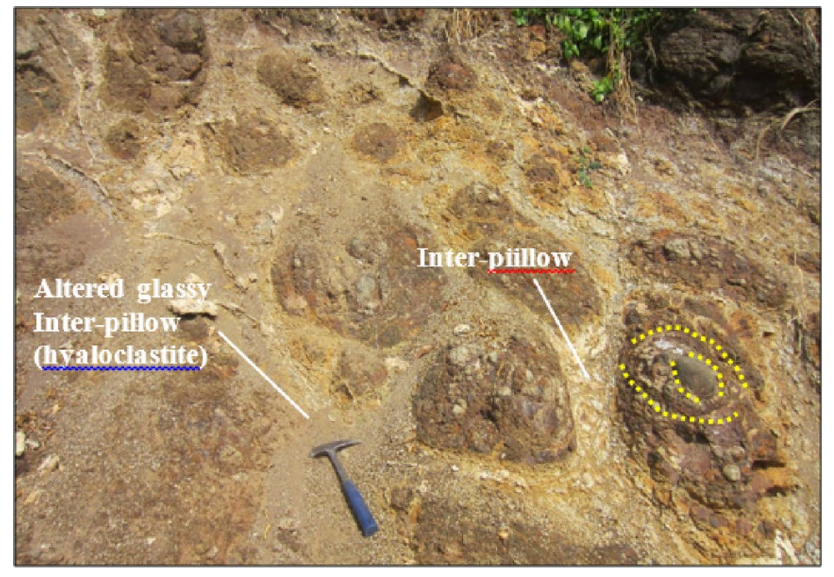

Fig. 12 The pillow lavas at Khao Ra Wang in the Lam Narai volcanic belt show developed joint, inter-pillow and altered glassy inter-pillow (hyaloclastite) at grid reference 724500E-1682000N (the hammer is $32 \mathrm{~cm}$ long)

by basic glassy pyroclastic association (hyaloclastite), especially those of basaltic composition. In the Lam Narai volcanic field, the clear evidence of pillow lava is exposed at the lower part of Khao Rawang. The pillow lavas composed of basaltic andesite lava flow area overlain by silicic pyroclastic rocks. The pillow shows as concentric features, highly weathering in the surface, inter-pillow and hyaloclastite (Fig. 12). According to Sheppard and Gude [11], Schmincke and von Rad [12], Viereck et al. [13], smectite formed rims on glass surfaces, replace both felsic and mafic glass, and pseudomorph glass shards and olivine crystals. The bentonite that is composed of almost smectite in the Khao Pa Khon area formed by basic glassy pyroclastic or hyaloclastite in basaltic layer and altered to smectite by hydrothermal alteration. The source of hydrothermal fluids is possibly derived from the major faults along Pa Sak River or the influence of the related to youngest intrusive rocks which exposed in the volcanic field and associated with sequences of felsic lavas.

However, bentonites in sedimentary sections carry information about source magma and tectonic processes in volcanic areas [14-17] and directions of volcanic sources [18]. To investigate the geology of bentonite deposits related to tectonic evolution of the volcanic terrane, isotopic dating of the well-preserved phenocrysts [19-21], trace element contents (immobile and mobile elements), analyzed from the bulk bentonite, are wildly and carefully used for interpretations [18].

\section{Conclusions}

Mineralogy and geochemistry of the bentonite deposits in association to the Lam Narai Volcanic Belt have been confirmed that the mineralization zone of the montmorillonite in smectite group formed in hydrothermal alteration of the parental basaltic layer. Pillow basalt and inter-pillow and altered grassy inter-pillow are indicated in the subaqueous environment and altered by hydrothermal fluid which possibly derived from the major fault along Pa Sak River or the youngest intrusive rocks in this area.

Acknowledgements This research was supported by the National Research Council of Thailand (NRCT) under the program Research Scholarships for Graduate Students, Chiang Mai University.

\section{Compliance with ethical standards}

Conflict of interest The authors declare that they have no conflict of interest.

\section{References}

1. Grim R, Güven N (1978) Bentonites, geology, mineralogy, properties and uses, development in sedimentology, vol 24. Elsevier, Amsterdam

2. Janyawanich C (1991) The research of industrial applications of bentonite (in Thai). Department of Mineral Resource, Bangkok

3. Barr S, Cooper MA (2013) Late Cenozoic basalt and gabbro in the subsurface in the Phetchabun Basin, Thailand: implications for the Southeast Asian Volcanic Province. J Asian Earth Sci 76:169-184. https://doi.org/10.1016/j.jseaes.2013.01.013

4. Jungyusuk N, Suriyachai P (1987) Geology on Ban Maha Pho, King Ampher Sri Thep, Ban Paniat and Amphoe Chai Badan. Geological survey report no. 0087(in Thai). Department of Mineral Resource, Bangkok, Thailand

5. Department of Mineral Resources (2001) Geology of Chai Badan 1:50,000 scale. Geological Survey Division, Department of Mineral Resources, Bangkok, Thailand

6. Winchester JA, Floyd PA (1977) Geochemical discrimination of different Magma series and their differentiation products using immobile elements. Chem Geol 20:325-343. https://doi. org/10.1016/0009-2541(77)90057-2

7. Mcdonough WF, Sun S-S (1995) The composition of the earth. Chem Geol 120:223-253. https://doi.org/10.1016/00092541(94)00140-4

8. Christidis GE (1998) Physical and chemical properties of some bentonite deposits of Kimolos Islands, Greece. Appl Clay Sci 13:79-98. https://doi.org/10.1016/S0169-1317(98)00023-4

9. Nesbitt HW, Young GM (1989) Formation and diagenesis of weathering profiles. J Geol 97:129-147. https://doi. org/10.1086/629290

10. Large R, Gemmell B, Paulick H, Huston DL (2001) The alteration box plot: a simple approach to understanding the relationship between alteration mineralogy and lithogeochemistry associated with volcanic-hosted massive sulfide deposits. Econ Geol 96(5):957-971. https://doi.org/10.2113/gsecongeo.96.5.957

11. Sheppard RA, Gude AJ (1968) Distribution and genesis of authigenic silicate minerals in tuffs of Pleistocene Lake Tecopa, Inyo 
County, California. United States Geological Survey Professional Paper 597

12. Schmincke H-U, von Rad U (1976) Neogene evolution of Canary Island volcanism inferred from ash layers and volcaniclastic sandstones of DSDP Site 397 (Leg 47A). In: Proceedings of the ocean drilling program, initial reports, vol 47, pp 703-726

13. Viereck LG, Griffin BJ, Schmincke H-U, Pritchard RG (1982) Volcaniclastic rocks of the Reydarfjordur drill hole, eastern Iceland: 2. Alteration. J Geophys Res 87:6459-6476. https://doi. org/10.1029/JB087iB08p06459

14. Huff WD, Merriman RJ, Morgan DJ, Roberts B (1993) Distribution and tectonic setting of Ordovician K-bentonites in the United Kingdom. Geol Mag 130:93-100. https://doi.org/10.1017/S0016 $75680002375 X$

15. Kiipli T, Soesoo A, Kallaste T (2014) Geochemical evolution of Caledonian volcanism recorded in the sedimentary rocks of the eastern Baltic region. In: Corfu F, Gasser D, Chew DM (eds) New perspectives on the Caledonides of Scandinavia and related areas, vol 390. Geological Society of London Special Publication, London, pp 177-192

16. Xing $L$, Zhou $M$, Qi L, Huang $Z$ (2015) Discussion on the PGE anomalies and source materials of K-bentonite (Bed 5) in the lower Cambrian Meishucun section, Yunnan. Chin J Geochem 34:346-361. https://doi.org/10.1007/s11631-015-0057-3

17. Huff WD (2016) K-bentonite: a review. Am Mineral 101:43-70. https://doi.org/10.2138/am-2016-5339
18. Kiipli T, Hints R, Kallaste T, Vers E, Voolma M (2017) Immobile and mobile elements during the transition of volcanic ash to bentonite-an example from the early Palaeozoic sedimentary section of the Baltic Basin. Sediment Geol 347:148-159. https:// doi.org/10.1016/j.sedgeo.2016.11.009

19. Sell B, Ainsaar L, Leslie S (2013) Precise timing of the Late Ordovician (Sandbian) super-eruptions and associated environmental, biological, and climatological events. J Geol Soc 170:711-714. https://doi.org/10.1144/jgs2012-148

20. Cramer BD, Schmitz MD, Huff WD, Bergstrom SM (2015) Highprecision $\mathrm{U}-\mathrm{Pb}$ zircon age constraints on the duration of rapid biogeochemical events during the Ludlow epoch (Silurian period). J Geol Soc 172:157-160. https://doi.org/10.1144/jgs20 14-094

21. Svensen $\mathrm{HH}$, Hammer O, Corfu F (2015) Astronomically-forced cyclicity in the Upper Ordovician and $\mathrm{U}-\mathrm{Pb}$ ages of interlayered tephra, Oslo Region, Norway. Palaeogeogr Palaeoclimatol Palaeoecol 418:150-159. https://doi.org/10.1016/j.palae 0.2014 .11 .001

Publisher's Note Springer Nature remains neutral with regard to jurisdictional claims in published maps and institutional affiliations. 